\title{
Derin Öğrenme ve Sınıflandırma Yaklaşımları ile BT görüntülerinden Covid-19 Tespiti
}

\section{Covid-19 Detection from CT images with Deep Learning and Classification Approaches} Erdal Özbay ${ }^{*}$, Feyza Altunbey Özbay

${ }^{1}$ Firat Üniversitesi, Bilgisayar Mühendisliği Bölümü, Elazı̆̆, erdalozbay@firat.edu.tr, 0000-0002-9004-4802

${ }^{2}$ Fırat Üniversitesi, Yazılım Mühendisliği Bölümü, Elazı̆̆, faltunbey@firat.edu.tr, 0000-0003-0629-6888

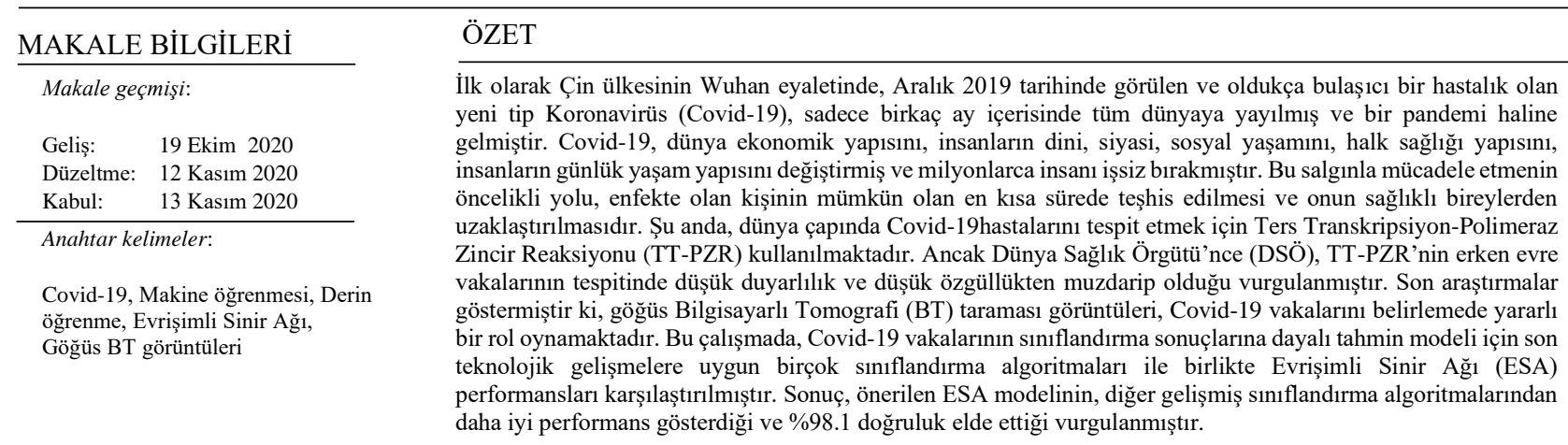

Doi: $10.24012 /$ dumf. 812810

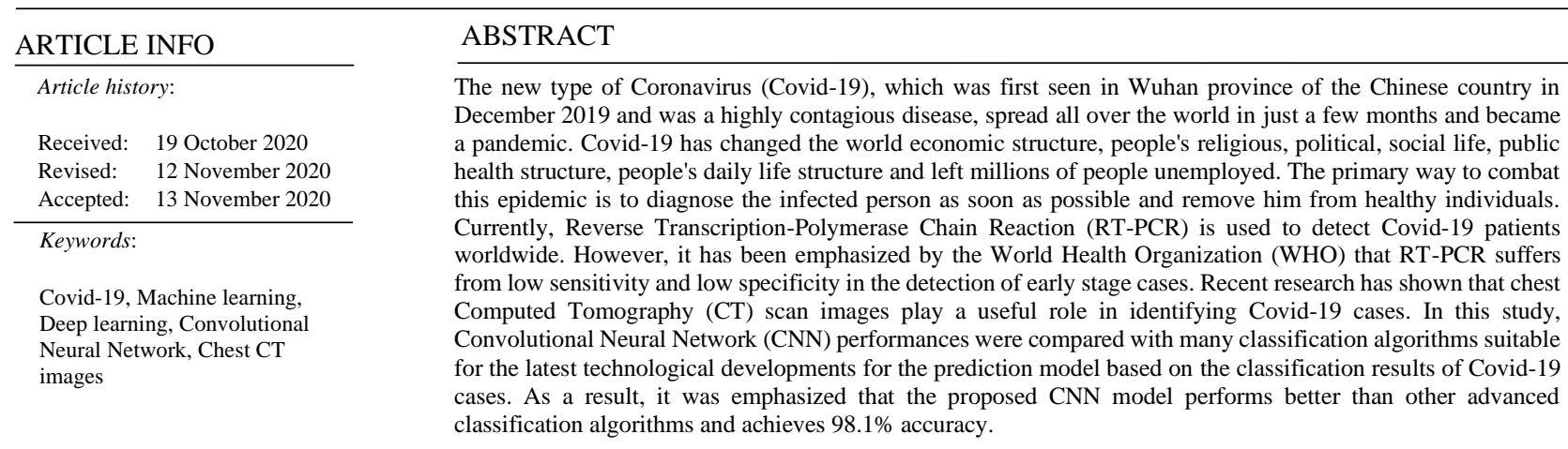

* Sorumlu yazar / Correspondence

Erdal ÖZBAY

$\triangle$ erdalozbay@ firat.edu.tr 


\section{Giriș}

Son bir yılda tüm dünyayı etkisi altına alan yeni tip Koronavirüs (Covid-19) hastalığ 2019 Aralık ayında Çin ülkesinin Wuhan kenti merkezli olarak ortaya çıkmış ve kısa bir zaman içerisinde de Çin'in her yerine yayılmıştır. Çok kısa bir sürede ise Çin dişına çıkarak tüm dünyada yayılmış ve dünya pandemisi haline gelmiştir. 17 Ekim 2020 itibariyle dünya çapında enfekte vaka sayıs1 39,644,861 ve ölüm vakası 1,110,182'dur [1]. Bu rakamlar, tüm dünyayı tehdit altına alan Covid-19'un ciddiye alınması gerektiğini göstermektedir. Bu bakımdan, Covid-19 vakaları erken tespit edilebilirse, bu hastalar tecrit edilebilir, böylelikle enfekte olmayan sağliklı bireyler güvende kalabilir. Şu anda, Covid-19 hastalarını teşhis etmenin küresel yöntemi, ters transkripsiyon-polimeraz zincir reaksiyonudur (TT-PZR). Ancak bu yöntemin birincil sorunu, düşük duyarlılık ve özgüllükten muzdarip olmasıdır [2]. Bunun yanında, uzak kırsal bölgelerde TT-PZR test kitlerinin azlığı nedeniyle, doktorlar Covid-19 taraması için tıbbi görüntülerin kullanılmasını önermektedir [3]. Bilgisayarlı tomografi (BT) tarama görüntüsü, pozitif Covid-19 hastalarının tespit edilmesi için önemli ayrıntılar taşımaktadır [4]. BT tarama görüntüsünün faydalarına rağmen, Covid-19 ve diğer akciğer hastalıkları arasında benzer özellikler bulunmaktadır. $\mathrm{Bu}$ bakımdan taramanın yürütülmesi oldukça zordur. Son zamanlarda, radyolojik görüntüler üzerinden, makine öğrenmesi ve derin öğrenme teknikleri kullanılarak bazı özelliklerin çıkarılması ve tespit edilmesi kullanışlı hale gelmiştir. Bu çalışmada, Covid-19 pozitif hastalarını, BT tarama görüntülerinden tespit etmek için birkaç makine öğrenimi ve derin öğrenme tekniği kullanılmaktadır. Veri seti, 1252 adet Covid-19 pozitif yani hasta, 1230 adet Covid-19 negatif yani sağlıklı olmak üzere toplam 2482 görüntüden oluşan nispeten büyük bir veri kümesinden oluşmaktadır. Sınıflandırma için bilinen en iyi sinıflandırıcı algoritmalarından Rastgele Orman, Destek Vektör Makinesi, Rastgele Ağaç ve Naive Bayes ile Evrişimli Sinir A ğ1 modelinin sonuçları karşılaştırılmış ve Covid-19 hastalarını en iyi doğrulayabilecek model belirlenmiştir. Makalenin geri kalan bölümü şu şekilde düzenlenmiştir; Bölüm 2, ilgili son çalışmaları ele almaktadır. Bölüm 3, bu çalışma için kullanılan veri setini ve yöntemleri tartışmaktadır. 4. Bölümde deneysel sonuçlar analiz edilmektedir ve önerilen Covid-19 tahmin modelinin deneysel sonuçlarının tartışılması ele alınmaktadır.

\section{İlgili Çalışmalar}

Pandeminin ortaya çıkışından itibaren, Covid-19 hastalığının tespiti için otomatik tarama sistemi, araştırma topluluğu için en önemli öncelik haline gelmiştir. Akciğerin BT taramalarının sınıflandırılması için otomatik bir sistemin geliştirilmesi, görsel bir incelemede bulaşıcı ve enflamatuar akciğer hastalıklarının teşhisinin karmaşıklığı nedeniyle zorlu olmaya devam etmektedir. Görsel muayene kabul edilebilir bir standart olmasına rağmen, teşhis edilmesi gereken çok sayıda hastadan kaynaklanan hatalara maruz kalma eğilimindedir. $\mathrm{Bu}$ bakımdan araştırmacılar, çeșitli yöntemlerle Covid-19'un benzersiz özelliklerini otomatik olarak belirlemek için birçok çalışma önermişlerdir.

Kang vd., Covid-19 için otomatik olarak teşhis koyabilen çok görüntülü bir temsil öğrenme tekniği önermişlerdir [5]. Önerdikleri modeli, doğrulamak için 2522 BT tarama görüntüsüne uygulamışlardır. Uyguladıkları yöntemle, sirasıyla \%95.5, \%96.6 ve \%93.2 doğruluk, duyarlılık ve özgüllüğe ulaşmışlardır. Li vd., gögüs BT'leriyle Covid-19'u doğru bir şekilde tanımlamak için bir derin öğrenme otomatik çerçevesi olan COVNet'i önermişlerdir [6]. Modellerini oluştururken 4356 görüntüden oluşan göğüs BT'si kullanmışlardır. Bu modelle, diğer pnömoni hastalarından Covid-19 hastalarını tespit etmede \% 87'lik bir duyarlılık ve 0.95 'lik bir Eğri Altındaki Alan (EAA) değeri elde edilmiştir. $\mathrm{Xu}$ vd., Covid-19'un erken taranması için ResNet adlı bir derin öğrenme modeli tasarlamışlardır [7]. Model oluşturulurken toplam 618 pulmoner BT örneği kullanılmıştır. $\mathrm{Bu}$ çalışmada, Covid-19'u influenza-A pnömonisinden ve sağliklı vakalardan ayıran \% 86,7'lik nihai bir doğruluk elde edilmiştir. Ardakani vd., Covid-19'u ayırt etmek için on adet evrişimli sinir ağını, yani VGG-16, VGG-19, AlexNet, GoogleNet, 
SqueezeNet, ResNet-18, ResNet-50, ResNet101, MobileNet-V2 ve Xception'1 1020 adet BT görüntüsü kullanarak diğer pnömonilerle (yani Covid-19 olmayan) karşılaştırmışlardır [8]. Bu bakımdan, ResNet 101 ve Xception'ın en yüksek EAA değeri olan 0.994'ü elde ettiğini gözlemlemişlerdir ve Covid-19 hastalarını karakterize etmek ve saptamak için Resnet 101'i önermişlerdir. Bir diğer çalışmada, Bai X. vd., derin bir sinir ağı mimarisi olan EfficientNet'i ortaya koymuş ve 1186 hastadan elde edilmiş BT karelerini bu mimariye uygulamışlardır [9]. Üretilen sistemde, Covid-19 ve Covid-19 olmayanlar arasında ayrım yapılırken, piyasaya sürülen sistemde $\% 96$ doğruluk, $\% 95$ duyarlılık ve \%96 özgüllük elde edilmiştir. Shi vd., Covid19'u taramak için bir makine öğrenimi algoritmas1 olan Rastgele Orman'1 (RO) uygulamışlardır [10]. Bu çalışma için sundukları modellerini değerlendirmek adına 2685 hastanın BT görüntülerini kullanmışlardır. Modelde, 5 kat çapraz doğrulama tekniği değerlendirildikten sonra, model sirasiyla $\% 87.9, \% 90.7$ ve $\% 83.3$ doğruluk, duyarlılık ve özgüllüğe ulaşmıştır. Bir başka çalışmada, Özkaya vd., 150 adet BT görüntüsünden 3000 adet yama görüntü üretmiş ve bu görüntüler üzerinden daha fazla siralama ve füzyon teknikleri uygulamışlardır [11]. Sınıflandırma için Destek Vektör Makinesi (DVM) kullanılmıştır ve bundan önce, transfer öğrenme yönteminin bir parçası olarak da önceden eğitilmiş olan bir ESA modeli kullanılmıştır. Sunulan prosedürde \%98,27 doğruluk, \%97,63 kesinlik ve \%97,6 duyarlılık elde edilmiştir. Alom vd., [12], Covid-19'u tespit etmek için verimli bir derin öğrenme yaklaşımı olan transfer öğrenmeli, Bölgesel-Evrişimli Sinir Ağı'nı (B-ESA) sunmuşlardır. Araştırmacılar daha önceleri, siniflandirmanın sonucunu artırabilmek için enfekte olan alan bölümlendirmesi için NABLA-N ağını kullanmışlardır. Önerilen yöntemin değerlendirilebilmesi için hem X-ışını hem de BT görüntüleri üzerinde çalışılmıştır. X-1şını ve BT görüntülerinden sirasiyla $\% 84.67$ ve $\% 98.78$ doğruluk değerleri elde etmişlerdir.

Mevcut sınıflandırma modelleri, özellik çıkarım karmaşıklığı açısından bazı sınırlamalar göstermektedir. Çeşitli özellik çıkarım algoritmaları, görüntü piksellerinin uzamsal dağılımındaki önemli değişikliklerini yakalamada önemli bir role sahiptir. Son zamanlarda, kesirli analiz ve uygulamaları farklı uygulama alanlarında kullanılmıştır [13]. Bu çalışmada, çalışmanın katkılarından biri olarak kabul edilen, görüntü sınıflandırma görevleri için akciğer BT taraması sınıflandırması için mevcut modeller, özellik çıkarma için yalnızca derin öğrenmeye dayanmaktadır. $\mathrm{Bu}$ nedenle, klinik bulgular ile derin öğrenme özelliklerini birleştirmek, Covid-19'lu ve sağlıklı vakalar arasındaki sınıflandırma performansını daha da artırarak hastalık hikayesinin seyrini olumlu biçimde etkileyecektir. $\mathrm{Bu}$ çalışmanın motivasyonu, derin öğrenme kullanarak BT taramalarında Covid-19'lu ve sağlıklı akciğerlerin verimli bir sınıflandırmasını önermektir.

\section{Materyal ve Metot}

\section{Veri Kümesi}

$\mathrm{Bu}$ araştırmada, Covid-19 hastalarını sınıflandırmak için, Kaggle adlı platform üzerinden halka açık şekilde paylaşılmış, BT tarama görüntülerinden oluşan bir veri seti kullanılmıştır [14]. Bu veri kümesinde Brezilya, Sao Paolo'dan toplanan 2482 göğüs BT görüntüsü bulunmaktadır.

a)

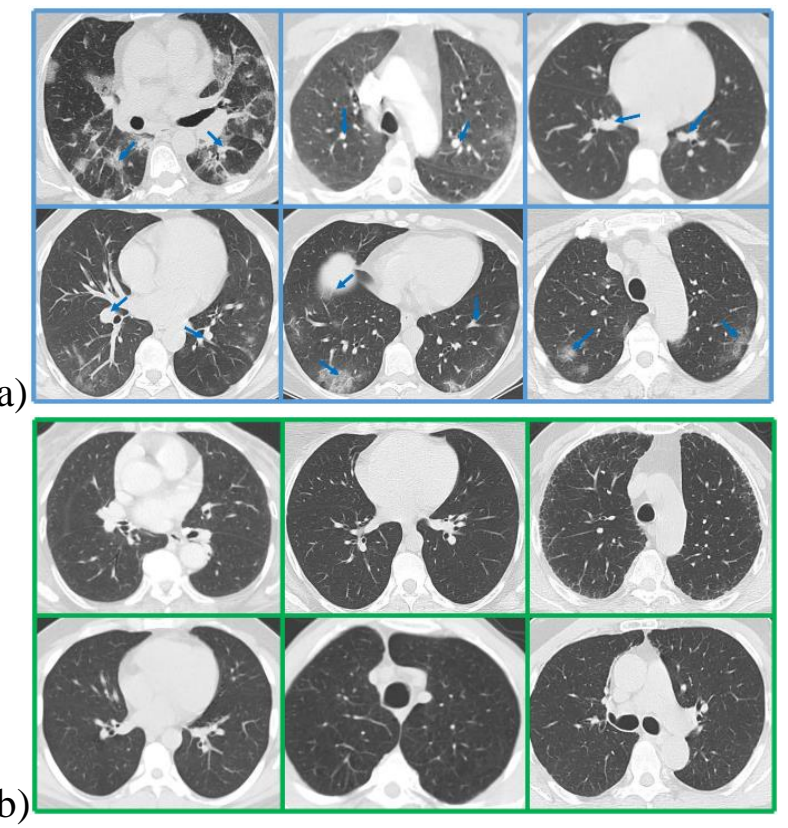

Şekil 1. Covid-19 vakaların BT tarama görüntü örnekleri, a) pozitif-mavi çerçeveli (mavi oklar kontamine bölgeyi göstermektedir), b) negatif-yeşil çerçeveli 
Veri kümesi içerisinde, 1252 tane pozitif Covid19 vakalı gögüs BT taraması görüntüsü ve 1230 negatif Covid-19 vakası anlamına gelen başka akciğer hastalıkları olan göğüs BT taraması görüntüleri bulunmaktadır. Bu veri kümesindeki göğüs BT tarama görüntülerinden bir kesit şekil 1 'de gösterilmiştir.

\section{Görüntü İşleme}

Veri kümesindeki görüntülerin tümü farklı boyutlardadır. Veri kümesindeki tüm görüntüleri aynı boyuta getirmek için Python Open CV kullanılarak, yeniden boyutlandırma işlemi yapılmıştır. Tüm görüntüler tek bir boyuta getirildikten sonra renk uzayı dönüşümü gerçekleştirilmiştir. $\mathrm{Bu}$ işlem ile, görüntüler RGB renk uzayından gri renk uzayına dönüştürülmüştür. Ön işleme aşaması, görüntülerin sınıflandırma algoritmalarında kullanılabilmesi için dizilere dönüştürülmesiyle tamamlanmıştır. Araştırma çalışmamızın akış diyagramı şekil 2'de gösterilmektedir.

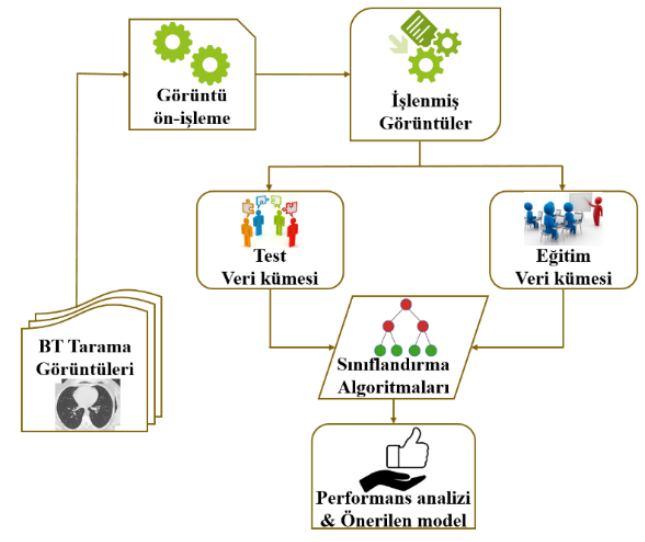

Şekil 2. Araştırma yöntem bilimimize ait akış diyagramı

\section{Sinıflandırma}

$\mathrm{Bu}$ çalışmada BT görüntülerini sınıflandırmak için beş adet farklı sınıflandırma algoritması yürütülmüştür.

\section{a. Evrişimsel Sinir Ağları (ESA)}

Son y1llarda, derin öğrenme, nesne tanıma, beyin tümörü segmentasyonu ve siniflandırma, meme kanseri tespiti, rahim ağzı kanseri tanıma gibi tıbbi problemlerin çözümünde oldukça ilgi çekmiştir. ESA, derin öğrenmenin bir parçasıdır ve bilgisayarla görme problemlerine sıklıkla uygulanmaktadır. ESA mimarisi, bir evrişim katman, bir havuzlama katmanı ve tamamen bağlantılı bir katman olmak üzere yapısında üç katmanın kombinasyonunu barındırmaktadır. İlk iki katman, giriş görüntüsünden derin özellikler çıkarır ve tamamen bağlantılı katman, çıkarılan özellikleri çıktı katmanına eşlemektedir. Böylelikle görüntünün gereksiz kısımlarının yapay sinir ağına gitmesi engellenerek, sistemin hızlı ve doğru sonuç vermesi sağlanmaktadır.

Evrişimli Katman: Evrişimli katman, özellik çıkarma işlemini gerçekleştirmektedir. Doğrusal evrişimli işlem ve doğrusal olmayan etkinleştirme fonksiyonu, evrişim adımını gerçekleştirmek için gereken iki temel işlemdir.

Doğrusal evrişimli süreçte, giriş görüntüsünden öznitelikleri çıkarmak için bir öznitelik algılayıcı veya çekirdek kullanılmaktadır. Bir özellik haritası veya aktivasyon haritası olarak da bilinen kıvrımlı bir görüntü oluşturmak için giriş tensörü ve çekirdek arasında eleman bazlı ürün operasyonu gerçekleştirilmektedir. Bu evrişimin birincil amac1, giriş görüntüsünün boyutunu azaltmaktır. Matematiksel olarak, aşağıdaki denklem evrişimli işlemi temsil etmektedir:

$(f * g)(t)=\int_{-\infty}^{+\infty} f(T) g(t-T) d T$

Evrişimden sonra, Doğrultulmuş Doğrusal Birim (Rectified Linear Unit- RELU) doğrusallığ kırmakta ve ağdaki doğrusal olmayışı geliştirmektedir. Fonksiyonun çıktısı aşağıdaki gibi özetlenmiştir:

$f(x)=\operatorname{maks}(0, x)$

Havuz Katmanı: Havuzlama, havuzlanmış özellik haritası oluşturmak için özellik haritasının boyutunu azaltmak için kıvrılmış görüntüden özellikler çıkarmaktadır. Maksimum havuzlama, ortalama havuzlama gibi farklı havuzlama türleri kullanılmaktadır. Daha sonra, havuzlanmış özellik haritası tek boyutlu bir sütun haline getirilmekte ve ek işlemler için yapay sinir ağına beslenmektedir.

Tamamen Bağlantılı Katman: Bu tam bağlant,, şekil 3'te gösterilen, tamamen bağlı bir katman aracılığıyla bir çıktı katmanına sahip bir giriş katmanından oluşan bir birleşimden oluşmaktadır. 


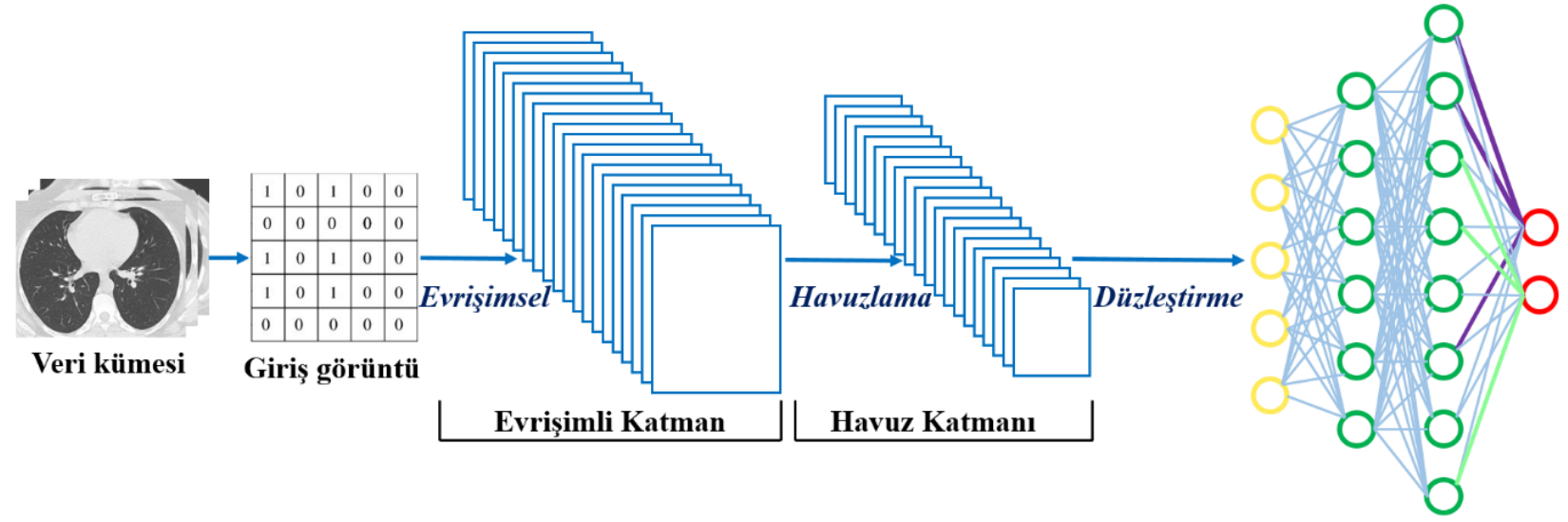

\section{Şekil 3. Evrişsimli Sinir Ağının (ESA) mimarisi}

Burada, tamamen bağlı katmanlar, tüm dügüumler tamamen bağlı olduğundan özel bir gizli katman olarak da bilinmektedir. Bu katmanlarda, RELU bir aktivasyon fonksiyonu olarak kullanılmaktadır.

Son tahmin, çıktı katmanında aktivasyon fonksiyonu olarak softmax veya sigmoid kullanılarak yapılmaktadır. Bilgi bu şekilde yapay sinir ağından geçmektedir. Ağın performansının değerlendirilmesi tahmin hatası veya kayıp fonksiyonunun 0'a yakınlığı ile ölçülmektedir. Ağ̀ optimize etmek için bu işlevin en aza indirilmesi gerekmektedir. Mükemmel bir tahmin elde etmek için, tahmin hatası ağ üzerinden geri yayılmaktadır.

\section{b. Rastgele Orman (RO)}

Popüler makine öğrenme modellerinden biri olan denetimli bir sınıflandırma yöntemidir, bu algoritmayı popüler yapan en önemli özelliği, hiper parametre kestirimi yapılmasına gerek duymadan iyi sonuçlar üretmesi ayrıca regresyon ve siniflandirma problemlerine uygulanabilmesidir. Algoritmanın temel çalışma prensibinde, modelin temel blogu olan karar ağaçları kullanılmaktadır. En basit şekliyle algoritma rastgele olarak bir orman yaratmaktadır, bu algoritmadaki ağaç sayısı ve elde edebileceği sonuç arasında doğrudan bir ilişki bulunmaktadır. Ağaç sayısı artırıldıkça daha kesin bir sonuç elde edilebilmektedir. Rastgele Orman algoritması ile Karar Ağacı algoritması arasındaki en önemli fark, Rastgele Orman yöntemindeki kök düğümün (Root Node) bulunması ve düğümlerin bölünmesi işlemlerinin rastgele çalışıyor olmasıdır. Rastgele Orman algoritmasında kullanılan model farklı veri setleri üzerinde eğitim gerçekleştirdiği için karar ağaçlarının en büyük problemlerinden olan varyans yani aşırı uyumluluk, diğer bir deyişle overfitting azalmaktadır [15].

\section{c. Destek Vektör Makinesi (DVM)}

Destek Vektör Makinesi (DVM), sınıflandırma ve regresyon problemlerini çözmek için kullanılan denetimli bir makine öğrenme algoritmasıdır. Destek vektörü makine modeli, çok boyutlu uzayda bir hiper düzlemdeki birkaç sınıfı temsil etmektedir. Hataları azaltmak için, hiper düzlem algoritma tarafından yinelemeli olarak oluşturulmakatadır. Algoritmanın temel amac1, veri kümelerini farklı sinıflara bölerek maksimum marjinal hiper düzlem elde etmektir.Bunlar iki adımda yapılmaktadır: İlk olarak, seviyeleri en iyi şekilde ayıran hiper düzlemler yinelemeli bir şekilde oluşturulmaktadır. İkinci olarak, sınıfları doğru bir şekilde ayıran alt düzlem seçilmektedir.

\section{d. Rastgele Ăgaç (RA)}

Rastgele Ağaç, birçok karar ağacından gelen tahminleri birleştiren bir toplu makine öğrenimi algoritmasıdır. Yaygın olarak kullanılan Rastgele Orman algoritması ile ilişkilidir. Grubun üyeleri olarak kullanılan karar ağaçlarını oluşturmak için daha basit bir algoritma kullanılmasına rağmen, genellikle rastgele orman algoritmasından daha iyi performans elde edilebilmektedir. Rastgele ağaç sınıflandırıcı, sinıflandırma ve regresyon için kullanılan, denetimli bir makine öğrenme algoritmasıdır. Rastgele ağaç sınıflandırıcı, eğitim veri setinden çok sayıda budanmamış karar ağacı 
oluşturmaktadır. Tahmin yapmak için, her karar ağacının oy verdiği yerlerde çoğunluk oylama tekniğini kullanmaktadır ve en yüksek oylanan tahmin, nihai siniflandirma sonucu olarak kabul edilmektedir. Her karar ağacı, bir ağaç ormanı oluşturmak için orijinal eğitim setinden oluşturulmaktadır. Her karar ağacı, özellik alt kümesinden verilen her test düğümündeki rastgele $k$ özellik örneğinden verileri ayırmak için en iyi özelliği seçmektedir. Daha sonra, birden fazla ilintisiz karar ağaçları olarak da bilinen fazladan ağaç ormanı, rastgele bir özellik örneği kullanılarak üretilmektedir.

\section{e. Naive Bayes (NB)}

Naive Bayes sınıflandırıcıları, Bayes teoreminin özellikleri arasında güçlü (naif) bağımsızlık varsayımlarıyla uygulamaya dayanan basit "olasılıksal sinıflandırıcılar" ailesidir. Naive Bayes sınıflandırıcıları, bir öğrenme problemindeki değişkenlerin (özellikler / öngörücüler) sayısında doğrusal bir dizi ölçeklendirilebilir parametre gerektirmektedir. Maksimum olasılık eğitimi, diğer birçok sınıflandırıcı türü için kullanılan pahalı yinelemeli yaklaşımdan ziyade doğrusal zaman alan kapal1 bir form ifadesinin değerlendirilmesiyle yapılabilmektedir. İstatistik ve bilgisayar bilimi literatüründe saf Bayes modelleri, basit Bayes ve bağımsız Bayes gibi çeşitli isimler adı altında bilinmektedir. Ancak tüm bu isimler, sınıflandırıcının karar kuralında Bayes teoreminin kullanımına atıfta bulunmaktadır. En basit Bayes ağ modelleri kernel yoğunluğu tahmini ile birleștirilebilmekte ve daha yüksek doğruluk seviyeleri elde edilebilmektedir.

\section{Performans Değerlendirme Ölçütleri}

$\mathrm{Bu}$ çalışmada, $k$-kat çapraz doğrulama tekniği kullanılarak veri kümesi $k$ farklı alt kümeye bölünerek önerilen sistemin verimliliği test edilmiștir. Herbir adımda, $k-1$ alt küme modeli eğitmek için, geri kalanı ise test kümesi olarak kullanılmıştır. Model oluşturma sırasında, bu işlem $k$ kez tekrarlanarak, modelin performansı, bağımsız $k$ alt kümenin test sonuçlarının ortalaması alınarak ölçülmektedir. Bu çalışmada $k$ değeri, 10 olarak belirlenmiştir. Bu çalışmada, altı (6) farklı değerlendirme ölçütü doğruluk, kesinlik, hassasiyet, F-ölçütü, özgüllük ve ROC eğrisi olarak bilinen Eğri Altındaki Alan (EAA) kullanılmıștır. Tablo 1'de verilen karışıklık matrisi, herhangi bir tahmin modelinin genel performansını göstermek için kullanılmaktadır. Bu karışıklık matrisi kullanılarak, belirlenen altı performans ölçütü hesaplanabilmektedir [16].

Tablo 1. Karışıklık Matrisi

\section{Tahmin Edilen}

\begin{tabular}{cccc}
\hline & & Pozitif & Negatif \\
\hline \multirow{4}{*}{ Gerçek } & \multirow{2}{*}{ Pozitif } & Doğru & Yanlış \\
& & Pozitif & Negatif \\
& & $($ DP) & (YN) \\
\cline { 2 - 4 } & \multirow{2}{*}{ Negatif } & Yanlış & Doğru \\
& & Pozitif & Negatif \\
& $($ YP) & (DN) \\
\hline
\end{tabular}

Doğruluk $=\frac{D P+D N}{D P+Y P+D N+Y N}$

Kesinlik $=\frac{D P}{D P+Y P}$

Duyarlılık $=\frac{D P}{D P+Y N}$

$F_{1}-$ Ölçütü $=\frac{2 * D P}{Y N+Y P+2 * D P}$

Özgüllük $=\frac{D N}{Y P+D N}$

Bu çalışmada EAA eğrisi, Covid-19 pozitif ve negatif iki durumun ne kadar doğru bir şekilde ayırdığını ölçmek için kullanılmaktadır. EAA eğrisi, DP oranının YP oranına göre değişiminin çizilmesiyle elde edilmektedir. Eğrinin Altındaki Alan'ın (EAA) fazlalığı tanı testinin başarısını göstermektedir. EAA, tüm olası sinıflandırma eşiklerinde toplu bir performans ölçüsü sağlamaktadır. EAA'1 yorumlamanın bir diğer şekli, modelin rastgele bir pozitif örneğinin, rastgele bir negatif örnekten daha yüksek bir şekilde sıralanması olasılığıdır.

\section{Deneysel Sonuçlar ve Tartışma}

$\mathrm{Bu}$ çalışmada, çeşitli uygulamalar geliştirmek için Google tarafindan sağlanan Python programlama diline dayalı bir bulut hizmeti olan Google Colab kullanılmıştır [17]. Daha hızlı 
işlem için sanal Tensör İşleme Birimi (TİB) kullanılmıştır. Deneysel veri setimiz \%75 : \%25 oranına bölünmüştür. $\mathrm{Bu}$ bakımdan veri kümemizdeki verilerin $\% 75^{\prime}$ i eğitim verisi olarak ve $\% 25$ 'i ise test verisi olarak kullanılmıştır. Modelin aşırı uyumlu olmasını önlemek için 10 kat çapraz doğrulama tekniği kullanılmıştır. $\mathrm{Bu}$ çalışmada, Covid-19 vakalarını sınıflandırmak için beş farklı sınıflandırma tekniği karşılaştırılmıştır. Deneysel sonuçlardan Covid19 hastalarının sinıflandırılmasında ESA, RO, DVM, RA ve NB'in sirasiyla \%98,1, \%85,45, $\% 84,6, \% 86,93$ ve $\% 87,77$ doğruluk sağladığ gösterilmiştir. Performansı değerlendirmek için dikkate alınan diğer istatistiksel değerlendirme ölçümleri tablo 2'de gösterilmektedir.

Tablo 2. Siniflandiricu algoritmalarin performans değerlendirme sonuçları

\begin{tabular}{|l|llllll|}
\hline $\begin{array}{l}\text { Sinıflandırıc1 } \\
\text { / Ölçütler }\end{array}$ & \multicolumn{1}{|l|}{ ESA } & RO & DVM & RA & NB \\
\hline Doğruluk & 98.10 & 85,45 & 84,6 & 86,93 & 87,77 \\
\hline Kesinlik & 94 & 81,4 & 80,73 & 82,5 & 81,64 \\
\hline Duyarlılık & 97,72 & 85,63 & 84,91 & 87,01 & 87,81 \\
\hline F1-Ölçütü & 95,81 & 83,46 & 82,76 & 84,68 & 83,67 \\
\hline Özgüllük & 97,37 & 85,32 & 84,34 & 86,63 & 85,41 \\
\hline EAA & 98,35 & 87,51 & 86,72 & 88,96 & 89,38 \\
\hline
\end{tabular}

Şekil 4'te, ESA sınıflandırıcısının Covid-19 sınıflandırması için tahmin performansı açısından diğer son teknoloji sınıflandırma algoritmalarından daha iyi performans gösterdiğini görebilmekteyiz.

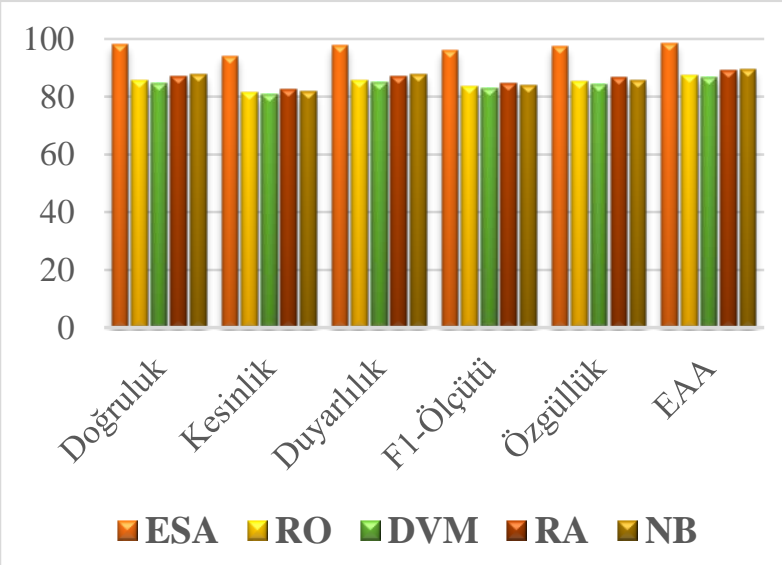

Şekil 4. Covid-19 tespiti için sinıflandırma algoritmalarının performans analizi
Önerilen tahmin modelinin detaylarıyla tartışılması gerekirse deneysel sonuçlar bölümünde, ESA sınıflandırıcısının, performans açısından diğer algoritmalardan daha iyi performans gösterdiği sayısal ve görsel olarak gösterilmiştir. $\mathrm{Bu}$ çalışmayla, önerilen ESA modelimizin gögüs BT taraması görüntüleri aracılığıyla Covid-19 vakalarının tespit edilmesi için kullanılabileceği söylenebilmektedir. Önerilen ESA modelinin tam yapısı şekil 5'te gösterilmektedir.

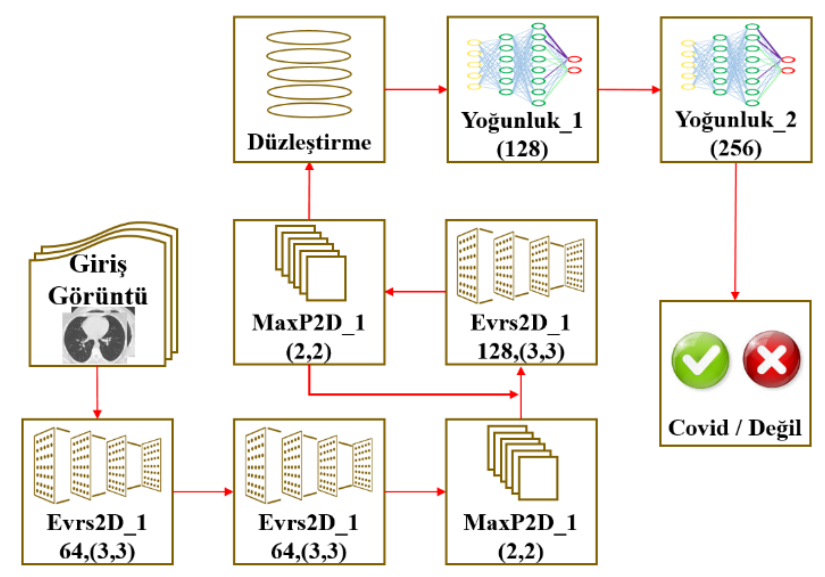

Şekil 5. Önerilen ESA modelinin yapısı

Deneysel sonuçlar için kullanılan veri kümesindeki görüntüler farklı boyutlarda olduğundan dolayı, görüntüler $64 \times 64$ piksellik sabit bir boyuta indirgenmiştir. Ardından, girdi görüntülerinden öznitelikleri çıkarmak için ilk evrişim katmanında $3 \times 3$ boyutunda 64 filtre kullanılmıştır. Birinci evrişim katmanının konfigürasyonuyla aynı şekilde ikinci bir evrişim katmanı daha eklenmiş ve aktivasyon fonksiyonu olarak ReLU kullanılmıştır. Daha sonra, 2x2 boyutunda Maksimum havuzlama, özellik haritasının boyutunu azaltmak için kullanılmıştır. 3x3 boyutunda 128 çekirdeğin bulunduğu bir başka evrişim katmanı daha eklenmiștir. Daha sonra, özellik haritasının boyutunu küçültmek için daha önce olduğu gibi Maksimum havuzlama eklenmiştir. Ardından son evrişim ve maksimum havuz katmanı tekrar eklenmiş ve ardından tek boyutlu bir diziye düzleştirilmiştir. Daha sonra 128 birim ve 256 birimlik toplam iki yoğun / gizli katman eklenmiştir, burada ReLU bir aktivasyon işlevi olarak kullanılmıștır. Nihai çıktı katmanında Covid-19 siniflandirmasıyla ilgili son tahmini almak için yalnızca bir düğüm kullanılmıştır. 
İkili bir sınıflandırma problemi olduğu için sigmoid fonksiyonunun bir aktivasyon fonksiyonu olarak benimsenmesinin nedeni budur. Optimize edici olarak önerilen ESA modeli, kayıp fonksiyonunu hesaplamak için ikili çapraz entropiyi kullanmaktadır. Önerilen ESA modelini daha sağlam hale getirmek ve aşırı uyumluluğu ve yetersiz uyumluluğu önlemek için, tüm operasyonlar devir olarak 100 adet, parti boyutu ise 32 olarak gerçekleştirilmiştir. Şekil 6'da, devrin başlarında eğitim kaybının son derece yüksek olduğu ve doğruluk oranının oldukça düşük olduğu gösterilmektedir. Ancak devir 100'e doğru yaklaştıkça, eğitim ve test kayıplarının 0'a yaklaşmasına karşılık, eğitim ve test doğruluklarının ise son derece yüksek değere ulaştığ 1 görülmektedir.

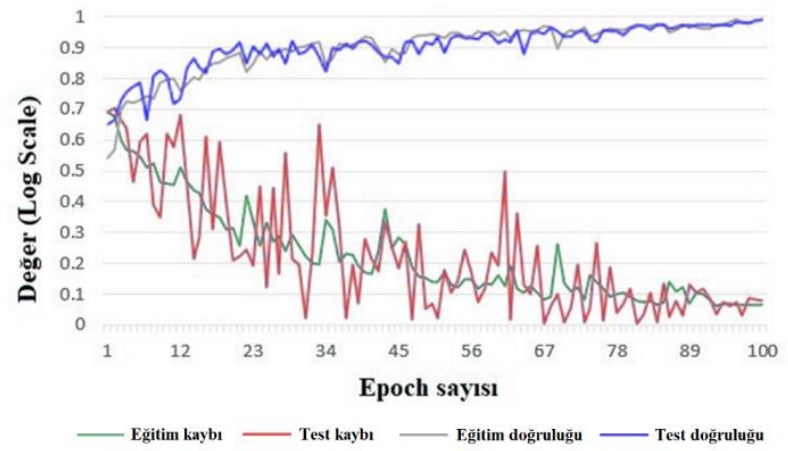

Şekil 6. Önerilen ESA modelin Eğitim, Test kaybı ve Ë̆itim, Test doğruluk ĕgrileri

Her adımda, ağırlıklar parti boyutlarına göre sürekli güncellenerek ağa iletilmektedir. Her devir dönemi tamamladıktan sonra, kayıp değeri kademeli olarak azalmakta ve doğruluk oranı artmaktadır. 100 devir döneminin tamamı tamamladiktan sonra, önerilen ESA modeli \%98,1 doğruluk elde etmiştir. ESA'nın genel test ve eğitim performansları tablo 3'te gösterilmektedir.

Tablo 3. Önerilen ESA modelinin test ve eğitim performans sonuçları

\begin{tabular}{|l|c|c|}
\hline $\begin{array}{l}\text { Sinıflandırıc1 } \\
\text { /Ölçütler }\end{array}$ & $\begin{array}{c}\text { Test } \\
\text { Performans1 }\end{array}$ & $\begin{array}{c}\text { Eğitim } \\
\text { Performans1 }\end{array}$ \\
\hline Doğruluk & 98.10 & 98,9 \\
\hline Kesinlik & 94 & 94,72 \\
\hline Duyarlılık & 97,72 & 97,8 \\
\hline F1-Ölçütü & 95,81 & 96,33 \\
\hline Özgüllük & 97,37 & 98,07 \\
\hline EAA & 98,35 & 99,07 \\
\hline
\end{tabular}

Ek olarak, önerilen ESA'nın test ve eğitim performansları şekil 7'de görsel olarak karşılaştırılmıştır.

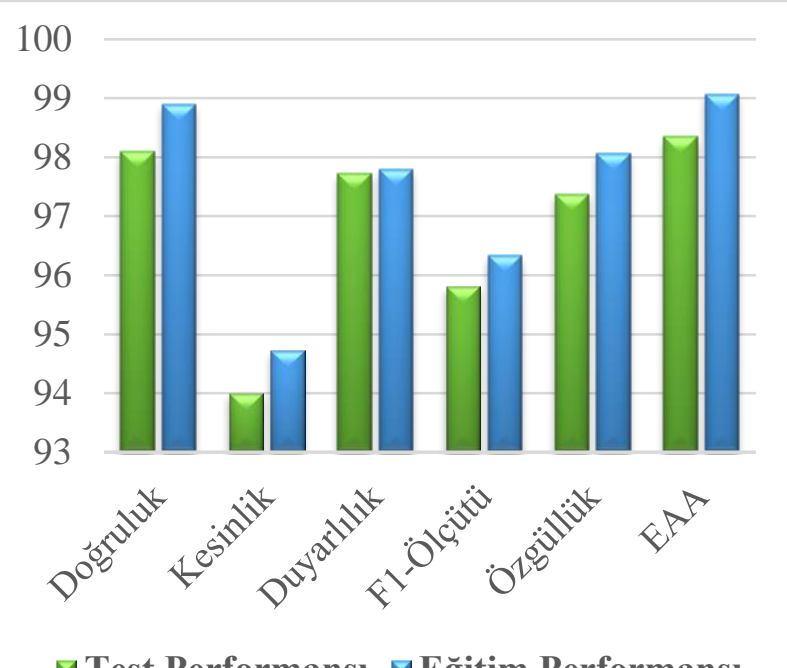

口Test Performansı $\square$ Eğitim Performansı

Şekil 7. Önerilen ESA modelinin Test ve Eğitim performanslarının karşılaştırılması

\section{Sonuçlar}

TT-PZR şu anda dünyanın hemen hemen tüm ülkelerinde Covid-19 tespiti için kullanılmaktadır. TT-PZR'nin yanlış negatif sonuçlar verebilmektedir ve aynı zamanda tüm dünyada bu TT-PZR kitlerinde aşırı bir eksiklik bulunmaktadır. $\mathrm{Bu}$ nedenle, yapay zeka tekniklerinin yanı sıra, göğüs BT tarama görüntüleri, bu sorunu çözmede ve insanlığın bu krizi aşmasına yardımcı olmakta aktif bir rol oynayabilmektedir. $\mathrm{Bu}$ çalışmada, Covid-19 hastalarını doğru bir şekilde tanımlamak ve sınıflandırmak için beş farklı makine öğrenimi ve derin öğrenme algoritması performansı karşılaştırılmıştır. $\mathrm{Bu}$ beş algoritmanın performansı analiz edildiğinde, ESA algoritmasının Covid-19 hastalarını tanımlamak için BT tarama görüntülerinden gizli bilgileri çıkarabildiği söylenebilmektedir. Önerilen ESA modeli \%98,10 gibi mükemmel bir doğruluk elde etmiştir. Önerilen bu model, yeterli tanımlama kitlerinin ve uzman hekimlerin olmadığı kırsal alanlarda TT-PZR ile birlikte alternatif bir araç veya yardımcı araç olarak kullanılabilecektir. $\mathrm{Bu}$ uygun maliyetli tahmin modeliyle, Covid-19 hastaları bir dakika içinde tespit edilebilecek, böylelikle hastalıktan etkilenen kişilerin diğer bireylerle olan teması kesilerek topluma 
bulaşının ve yayılmanın önüne geçilebilecektir. Covid-19 vakalarının büyük veri kümesine kolayca erişilememesi nedeniyle, bu araştırmada, kullanıma açık olan 2482 görüntüden oluşan bir veri kümesi kullanılmıştır. Boyutu daha büyük bir veri kümesi kullanılabilseydi, Covid-19 hastalarını belirlemek için daha sağlam bir tahmin modeli geliştirilebilirdi. $\mathrm{Bu}$ tahmin modeli, göğüs BT tarama görüntülerini girdi olarak almakta ve bir dakika içerisinde sonuç verebilmektedir. Tüm deneysel sonuçları elde etmek için $2.3 \mathrm{GHz}$ ve $8 \mathrm{~GB}$ RAM'e sahip Intel Core i7 işlemcili bir sistem kaynağ kullanılmıştır. Çalışmada, yapılan deneysel sonuçlarla önerilen modelin yüksek doğruluğa sahip değerlere ulaşabildiği ortaya konmuştur.

\section{Kaynaklar}

[1] "Coronavirus Update" [Online] Erişim: https://www.worldometers.info/coronavirus/, 17.10.2020.

[2] Bleve, G., Rizzotti, L., Dellaglio, F., Torriani, S., (2003). Development of reverse transcription (RT)PCR and real-time RT-PCR assays for rapid detection and quantification of viable yeasts and molds contaminating yogurts and pasteurized food products. Applied and Environmental Microbiology, 69, 7, 4116-4122.

[3] Long, C., Xu, H., Shen, Q., Zhang, X., Fan, B., Wang, C., Li, H., (2020). Diagnosis of the Coronavirus disease (COVID-19): rRT-PCR or CT?. European journal of radiology, 108961.

[4] Dong, D., Tang, Z., Wang, S., Hui, H., Gong, L., Lu, Y., Jin, R., (2020). The role of imaging in the detection and management of COVID-19: a review. IEEE reviews in biomedical engineering.

[5] Kang, H., Xia, L., Yan, F., Wan, Z., Shi, F., Yuan, H., Shen, D., (2020). Diagnosis of coronavirus disease 2019 (covid-19) with structured latent multi-view representation learning. IEEE transactions on medical imaging.

[6] Li, L., Qin, L., Xu, Z., Yin, Y., Wang, X., Kong, B., Cao, K., (2020). Artificial intelligence distinguishes COVID-19 from community acquired pneumonia on chest CT. Radiology.
[7] Butt, C., Gill, J., Chun, D., Babu, B. A., (2020). Deep learning system to screen coronavirus disease 2019 pneumonia. Applied Intelligence, 1.

[8] Ardakani, A. A., Kanafi, A. R., Acharya, U. R., Khadem, N., Mohammadi, A., (2020). Application of deep learning technique to manage COVID-19 in routine clinical practice using CT images: Results of 10 convolutional neural networks. Computers in Biology and Medicine, 103795

[9] Bai, H. X., Wang, R., Xiong, Z., Hsieh, B., Chang, K., Halsey, K., Mei, J., (2020). AI augmentation of radiologist performance in distinguishing COVID-19 from pneumonia of other etiology on chest CT. Radiology, 201491.

[10] Shi, F., Xia, L., Shan, F., Wu, D., Wei, Y., Yuan, H., Shen, D., (2020). Large-scale screening of covid-19 from community acquired pneumonia using infection size-aware classification. arXiv preprint arXiv:2003.09860.

[11] Ozkaya, U., Ozturk, S., Barstugan, M., (2020). Coronavirus (COVID-19) Classification using Deep Features Fusion and Ranking Technique. arXiv preprint arXiv:2004.03698.

[12] Alom, M. Z., Rahman, M. M., Nasrin, M. S., Taha, T. M., Asari, V. K., (2020). COVID_MTNet: COVID19 Detection with Multi-Task Deep Learning Approaches. arXiv preprint arXiv:2004.03747.

[13] Yang, X. J., Gao, F., Ju, Y., (2020). General fractional derivatives with applications in viscoelasticity. Academic Press.

[14] "SARS-COV-2 Ct-Scan Dataset." Eduardo S., Plamen A., [Online] Erişim: Kaggle, doi: 10.34740/KAGGLE/DSV/1100240, 17.10.2020.

[15] Pal, M., (2005). Random forest classifier for remote sensing classification. International journal of remote sensing, 26, 1, 217-222.

[16] Özbay, E., Çinar, A., (2019). A Comparative Study of Object Classification Methods Using 3D Zernike Moment on 3D Point Clouds. Traitement du Signal, 36, 6, 549-555.

[17] "Google Colab" [Online] Erişim: https://colab.research.google.com/, 17.10.2020. 